\title{
Virgibacillus kekensis sp. nov., a moderately halophilic bacterium isolated from a salt lake in China
}

\author{
Yi-Guang Chen, ${ }^{1,2}$ Xiao-Long Cui, ${ }^{1}$ Dagmar Fritze, ${ }^{3}$ Li-Hong Chai, ${ }^{4}$ \\ Peter Schumann, ${ }^{3}$ Meng-Liang Wen, ${ }^{1}$ Yong-Xia Wang, ${ }^{1}$ Li-Hua Xu ${ }^{1}$ \\ and Cheng-Lin Jiang ${ }^{1}$
}

Correspondence
Li-Hua Xu
lihxu@ynu.edu.cn
Xiao-Long Cui
xlcuiynu@yahoo.com.cn

At the time of writing, the genus Virgibacillus comprises 11 recognized species, with Virgibacillus olivae (Quesada et al., 2007) and Virgibacillus halophilus (An et al., 2007) being the most recently described. Virgibacillus pantothenticus (Heyndrickx et al., 1998) is the type species. During a recent study of the microbial diversity of the Keke salt lake in the Qaidam Basin of Qinghai Province, north-west China, a moderately halophilic rod-shaped bacterium, designated strain YIM kkny16 ${ }^{\mathrm{T}}$, was isolated from a saline mud sample. Phenotypic and chemotaxonomic characterization, together with phylogenetic analysis based on $16 \mathrm{~S}$ rRNA gene sequences, showed that strain YIM kkny16

The GenBank/EMBL/DDBJ accession number for the $16 \mathrm{~S}$ rRNA gene sequence of strain $\mathrm{YIM}$ kkny $16^{\top}$ is $A Y 121439$. was related to members of the genus Virgibacillus, but represented a novel species.

Strain YIM kkny $16^{\mathrm{T}}$ was isolated from a saline mud sample by plating $1: 10$ serial dilutions of the sample on Difco marine agar 2216 (MA; pH 7.2) at $28{ }^{\circ} \mathrm{C}$ for 2 weeks. The strain was maintained both in Difco marine broth (MB) supplemented with $20 \%(\mathrm{v} / \mathrm{v})$ glycerol at $-80{ }^{\circ} \mathrm{C}$ and as lyophilized cultures at $4{ }^{\circ} \mathrm{C}$. Unless otherwise indicated, morphological and physiological studies were performed with cells grown on MA supplemented with $10 \%(\mathrm{w} / \mathrm{v})$ $\mathrm{NaCl}$, and on ISP medium 2 agar (Shirling \& Gottlieb, 1966), nutrient agar and trypticase soy agar (BBL) as controls. Cells for chemotaxonomic and molecular systematic studies were grown in MB supplemented with $10 \%$ $(\mathrm{w} / \mathrm{v}) \mathrm{NaCl}$ in shake flasks (with shaking at about 
180 r.p.m.) at $37{ }^{\circ} \mathrm{C}$ for 3 days. Biomass was harvested by centrifugation and washed twice with distilled water.

Cell morphology was examined by using phase-contrast microscopy (Zeiss Axioscope, $\times 100$ Plan-Neofluar oilimmersion objective, Ph3; agar-slide technique; Zeiss Axiocam MRc, Software Axiovision) with cells grown on MA plus $10 \mathrm{mg} \mathrm{MnSO}_{4}$ for 2 days at $30{ }^{\circ} \mathrm{C}$ and for 7 days at room temperature $\left(18-20{ }^{\circ} \mathrm{C}\right)$. Gram staining was carried out by using the standard Gram reaction (Doetsch, 1981) combined with the KOH lysis test method (Gregersen, 1978). Endospores were stained according to the method of Schaeffer-Fulton (Smibert \& Krieg, 1981). Anaerobic growth was determined by using a BBL Anaerobic System pot according to the manufacturer's instructions. Motility was observed both on MB solidified with $0.3 \%$ agar under high-moisture conditions and in a hanging-drop preparation under a $\times 100$ oil-immersion objective.

Optimum growth was tested at different temperatures (4, $10,15,20,28,37,45,50$ and $55{ }^{\circ} \mathrm{C}$ ) and different salt concentrations $[0,0.5,1.0,2.03 .0,4.0,5.0,10.0,15.0,20.0$, 25.0 and $30.0 \%(\mathrm{w} / \mathrm{v}) \mathrm{NaCl}]$ on $\mathrm{MA}$ and in $\mathrm{MB}$, and at different $\mathrm{pH}$ values (5.0, 6.0, 7.0, 8.0, 9.0 and 10.0) in $\mathrm{MB}$ plus $10 \%(\mathrm{w} / \mathrm{v}) \mathrm{NaCl}$. For $\mathrm{pH}$ experiments, the buffer solutions described by Chen et al. (2004) were used. For the catalase test, the evolution of bubbles upon addition of $3 \%$ $\mathrm{H}_{2} \mathrm{O}_{2}$ solution to cells was observed under a stereoscopic microscope. Oxidase activity was tested by the oxidation of $1 \%(\mathrm{w} / \mathrm{v})$ tetramethyl- $p$-phenylenediamine (bioMérieux). Hydrolysis of polymers, urease activity, nitrate reduction, and Voges-Proskauer and methyl red tests were determined as described by Gerhardt et al. (1981) and Atlas (1993). Virgibacillus marismortui DSM $12325^{\mathrm{T}}$ and Virgibacillus halodenitrificans DSM $10037^{\mathrm{T}}$ were employed in these tests as controls. Substrate utilization as sole carbon and energy source, activities of constitutive enzymes and other physiological characteristics were carried out by using API 20E, API 20NE, API 50CH (with API $50 \quad \mathrm{CH} \quad \mathrm{B} / \mathrm{E}$ medium) and API ZYM strips (bioMérieux) and Biolog GP2 microplates according to the manufacturers' instructions. All suspension media were supplemented with $10 \% \mathrm{NaCl}$. Antibiotic-sensitivity tests were performed by inoculating the bacterial suspension on MA plus $10 \% \mathrm{NaCl}$ at $37{ }^{\circ} \mathrm{C}$, and applying AntibioticsSensitabs (Tiantan Medicine Co.). Inhibition zones were measured after 5 days incubation and interpreted according to the manufacturer's manual.

Amino acid and sugar analyses of whole-cell hydrolysates were performed as described by Hasegawa et al. (1983) and Staneck \& Roberts (1974), respectively. Polar lipids were extracted according to the method of Minnikin et al. (1979), and were identified by two-dimensional TLC and spraying with specific reagents (Collins \& Jones, 1980). Menaquinones were analysed by HPLC as described by Groth et al. (1996), and the menaquinones of $V$. marismortui DSM $12325^{\mathrm{T}}$ and V. halodenitrificans DSM
$10037^{\mathrm{T}}$ were analysed in parallel with those of strain YIM kkny $16^{\mathrm{T}}$ under identical conditions. Cells were prepared as described by Lee et al. (2006) and An et al. (2007), and cellular fatty acid methyl esters were identified according to the standard protocol of the Microbial Identification system (MIDI; Microbial ID).

DNA was isolated according to Hopwood et al. (1985) and the $\mathrm{G}+\mathrm{C}$ content was determined by the thermaldenaturation method (Mandel \& Marmur, 1968) with a Shimadzu UV-visible spectrophotometer (UV1601). Genomic DNA extraction, PCR-mediated amplification of the 16S rRNA gene and purification of PCR products were performed as described by Cui et al. (2001). The resulting 16S rRNA gene sequence of strain YIM kkny $16^{\mathrm{T}}$ was compared with sequences obtained from public databases to find its most closely related phylogenetic neighbours. Phylogenetic analyses were performed by using the software package MEGA version 3.1 (Kumar et al., 2004) after multiple alignment of sequence data by CLUSTAL_X (Thompson et al., 1997). Distances (corrected according to Kimura's two-parameter model; Kimura, 1980) were calculated and clustering was performed with the neighbour-joining method (Saitou \& Nei, 1987). Maximumparsimony (Kluge \& Farris, 1969) trees (not shown) were generated by using the treeing algorithm contained within the PHYLIP package (Felsenstein, 1993). Bootstrap analysis was used to evaluate the tree topology of the neighbourjoining data based on 1000 resamplings (Felsenstein, 1985). DNA-DNA hybridizations were carried out by using photobiotin-labelled probes in microplate wells as described by Ezaki et al. (1989). A microplate spectrofluorometer (Gemini XPS; Molecular Devices) was employed for fluorescence measurements.

Cells of strain YIM kkny16 ${ }^{\mathrm{T}}$ were Gram-positive rods, approximately $2.0-3.0 \times 0.3-0.5 \mu \mathrm{m}$, occurring singly or in pairs. Cells were motile and strictly aerobic. Terminal ellipsoidal spores were observed in swollen sporangia (Fig. 1). Filaments were not observed during the cell life cycle. Colonies were circular to slightly irregular, raised, translucent, creamy grey-coloured, slightly transparent at the edges and $2-3 \mathrm{~mm}$ in diameter after incubation for 3 days at $37{ }^{\circ} \mathrm{C}$ on MA plus $10 \%(w / v) ~ N a C l$. No soluble pigments were produced on any of the media tested. The results of other phenotypic tests are summarized in the species description below and in Table 1 .

Chemotaxonomic data for strain YIM kkny16 ${ }^{\mathrm{T}}$ were consistent with its assignment to the genus Virgibacillus (Heyndrickx et al., 1998; Heyrman et al., 2003). The peptidoglycan of strain YIM kkny16 ${ }^{\mathrm{T}}$ contained mesodiaminopimelic acid. Galactose, glucose and ribose were present in the whole-cell hydrolysates. The fatty acid profiles of strain YIM kkny $16^{\mathrm{T}}$ and of the type strains of related Virgibacillus species are given in Table 2. The major fatty acids of strain YIM kkny16 ${ }^{\mathrm{T}}$ were anteiso- $\mathrm{C}_{15: 0}$ (50.4\%), iso- $\mathrm{C}_{14: 0}(13.3 \%), \mathrm{C}_{16: 1} \omega 7 c$ alcohol (8.1\%), anteiso- $\mathrm{C}_{17: 0} \quad(7.0 \%)$ and iso- $\mathrm{C}_{16: 0} \quad(6.1 \%)$. MK-7 


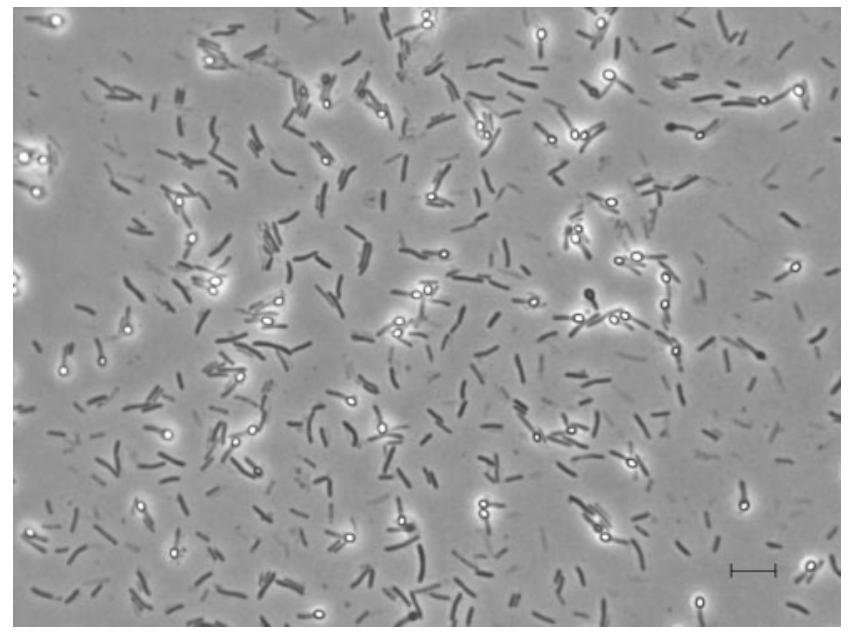

Fig. 1. Photomicrograph of sporangia and vegetative cells of strain YIM kkny $16^{\top}$; sporangia are swollen with terminal ellipsoidal or spherical spores. Bar, $5 \mu \mathrm{m}$.

(93.2\%) was the predominant menaquinone, with MK-6 $(6.1 \%)$ and MK-8 (0.7\%) present in minor amounts. Diphosphatidylglycerol, phosphatidylglycerol and two unknown phospholipids were found as polar lipids.

The genomic DNA G $+\mathrm{C}$ content of strain YIM kkny $16^{\mathrm{T}}$ was $41.8 \mathrm{~mol} \%$. The almost-complete $16 \mathrm{~S}$ rRNA gene sequence (1562 bp) of strain YIM kkny $16^{\mathrm{T}}$ was determined. Phylogenetic analysis based on 16S rRNA gene sequences revealed that strain YIM kkny16 ${ }^{\mathrm{T}}$ was related closely to members of the genus Virgibacillus, with sequence similarities of between $94.9 \%$ (to Virgibacillus salexigens DSM $11483^{\mathrm{T}}$ ) and $97.3 \%$ (to $V$. olivae DSM $18098^{\mathrm{T}}$ ). Strain YIM kkny16 ${ }^{\mathrm{T}}$ showed next-highest $16 \mathrm{~S}$ rRNA gene sequence similarities to $V$. marismortui DSM $12325^{\mathrm{T}}(97.2 \%)$ and $V$. halodenitrificans DSM $10037^{\mathrm{T}}$ $(96.7 \%)$. However, the neighbour-joining dendrogram (Fig. 2) showed that strain YIM kkny $16^{\mathrm{T}}$ formed a distinct lineage, which indicated that it probably represented a novel species of the genus Virgibacillus. To establish the precise taxonomic position of strain YIM kkny16 ${ }^{\mathrm{T}}$, DNADNA hybridizations were carried out with $V$. marismortui DSM $12325^{\mathrm{T}}$ and V. halodenitrificans DSM $10037^{\mathrm{T}}$. Levels of DNA-DNA relatedness between strain YIM kkny16 ${ }^{\mathrm{T}}$ and the above two type strains were 25.8 and $20.2 \%$, respectively. These values were far below the threshold value of $70 \%$ recommended by Wayne et al. (1987) for assigning strains to the same species. It is therefore evident, based on the phylogenetic analysis and DNA-DNA hybridization data, that strain YIM kkny16 ${ }^{\mathrm{T}}$ does not belong to either $V$. marismortui or $V$. halodenitrificans. $V$. olivae DSM $18098^{\mathrm{T}}$ shared $99.8 \% 16 \mathrm{~S}$ rRNA gene sequence similarity with $V$. marismortui DSM $10037^{\mathrm{T}}$, and these two strains formed a sub-branch in the phylogenetic tree with significant bootstrap support (100\%) (Fig. 2); however, the level of DNA-DNA relatedness $(46.5 \%)$ between the two strains was well below the threshold value recommended by Wayne et al. (1987). Although the level of 16S rRNA gene sequence similarity of $97.3 \%$ between strain YIM kkny $16^{\mathrm{T}}$ and $V$. olivae DSM $18098^{\mathrm{T}}$ was slightly higher than the threshold value of $\geqslant 97 \%$ recommended by Stackebrandt \& Goebel (1994) for assigning strains to the same species, the unattached status of the branches occupied by strain YIM kkny16 ${ }^{\mathrm{T}}$ and $V$. olivae DSM $18098^{\mathrm{T}}$ in the phylogenetic tree (Fig. 2), together with the significant difference in genomic DNA $\mathrm{G}+\mathrm{C}$ content $(8.4 \mathrm{~mol} \%)$ between the two strains, was sufficient to indicate that strain YIM kkny16 ${ }^{\mathrm{T}}$ does not belong to $V$. olivae (Stackebrandt \& Liesack, 1993). Futhermore, Stackebrandt \& Ebers (2006) suggested an increase from 97.0 to $98.7-99.0 \% 16 \mathrm{~S}$ rRNA gene sequence similarity for the threshold to delineate separate species, provided that these data are supported by clear phenotypic differences. On this basis, our phylogenetic analyses suggest strongly that strain YIM kkny16 ${ }^{\mathrm{T}}$ does not belong to any of the 11 recognized Virgibacillus species.

Phenotypic evidence supported the placement of strain YIM kkny $16^{\mathrm{T}}$ within the genus Virgibacillus (Heyndrickx et al., 1998; Heyrman et al., 2003); however, strain YIM kkny $16^{\mathrm{T}}$ could be distinguished from recognized Virgibacillus species based on its morphological, physiological and biochemical properties, together with chemotaxonomic data (Tables 1 and 2). Strain YIM kkny16 ${ }^{\mathrm{T}}$ differed from recognized species of the genus Virgibacillus based on the presence of noticeable amounts of MK-6 $(6.1 \%)$ and iso- $\mathrm{C}_{14: 0}(13.3 \%)$ and $\mathrm{C}_{16: 1} \omega 7 c$ alcohol $(8.1 \%)$, together with its wide growth-temperature range $\left(10-50{ }^{\circ} \mathrm{C}\right)$. Strain YIM kkny16 ${ }^{\mathrm{T}}$ also differed from its three closest phylogenetic relatives ( $V$. olivae DSM $18098^{\mathrm{T}}, V$. marismortui DSM $12325^{\mathrm{T}}$ and $V$. halodenitrificans DSM $10037^{\mathrm{T}}$ ) by its ability to grow at $\mathrm{pH} 10$ and inability to hydrolyse gelatin (Table 1). In addition, strain YIM kkny $16^{\mathrm{T}}$ could be differentiated clearly from $V$. olivae based on DNA G $+C$ content and fatty acid content; strain YIM kkny $16^{\mathrm{T}}$ contained significantly lower amounts of iso$\mathrm{C}_{15: 0}(2.6 \%)$ and iso- $\mathrm{C}_{17: 0}(0.28 \%)$ than $V$. olivae DSM $18098^{\mathrm{T}}$, but a greater amount of anteiso- $\mathrm{C}_{15: 0}(50.4 \%)$ (Table 2).

On the basis of phylogenetic analysis, phenotypic distinctiveness, genomic DNA $\mathrm{G}+\mathrm{C}$ content and DNA-DNA relatedness data, we propose that strain YIM kkny16 ${ }^{\mathrm{T}}$ represents a novel species of the genus Virgibacillus, for which the name Virgibacillus kekensis sp. nov. is proposed.

\section{Description of Virgibacillus kekensis sp. nov.}

Virgibacillus kekensis (ke.ken'sis. N.L. masc. adj. kekensis pertaining to salt lake Keke in Qinghai Province, northwest China, where the type strain was isolated).

Cells are strictly aerobic, motile, Gram-positive rods $(2.0-3.0 \times 0.3-0.5 \mu \mathrm{m})$ that occur singly, in pairs or in short chains. They bear ellipsoidal endospores that lie in terminally swollen sporangia. After 3 days on MA 
Table 1. Differential characteristics between strain YIM kkny $16^{\top}$ and recognized species of the genus Virgibacillus

Taxa: 1, strain YIM kkny16 ${ }^{\mathrm{T}}$ (data from the present study); 2, V. marismortui (Arahal et al., 1999, 2000; Heyrman et al., 2003); 3, V. halodenitrificans (Yoon et al., 2004); 4, V. olivae (Quesada et al., 2007); 5, V. carmonensis (Heyrman et al., 2003); 6, V. proomii (Heyndrickx et al., 1999; Heyrman et al., 2003); 7, V. pantothenticus (Heyndrickx et al., 1999; Heyrman et al., 2003); 8, V. dokdonensis (Yoon et al., 2005); 9, V. necropolis (Heyrman et al., 2003); 10, V. salexigens (Garabito et al., 1997; Wainø et al., 1999; Heyrman et al., 2003); 11, V. koreensis (Lee et al., 2006); 12, V. halophilus (An et al., 2007). +, Positive; -, negative; $\mathrm{v}$, variable; $\mathrm{w}$, weakly positive; pr, predominant amount; tr, trace; ND, no data available. Data in parentheses are for type strains.

\begin{tabular}{|c|c|c|c|c|c|c|c|c|c|c|c|c|}
\hline Characteristic & 1 & 2 & 3 & 4 & 5 & 6 & 7 & 8 & 9 & 10 & 11 & 12 \\
\hline Spore shape & $\mathrm{E}, \mathrm{S}$ & $\mathrm{E}$ & $\mathrm{E}$ & $S, E$ & $\mathrm{E}, \mathrm{S}$ & S, E & S, E & $S, E$ & $\mathrm{E}$ & $\mathrm{E}$ & $\mathrm{E}$ & $\mathrm{E}$ \\
\hline Spore position $\dagger$ & $\mathrm{T}$ & $\mathrm{T}, \mathrm{ST}$ & $\mathrm{T}, \mathrm{ST}$ & $\mathrm{T}, \mathrm{ST}$ & ST & $\mathrm{T}, \mathrm{ST}$ & $\mathrm{T}, \mathrm{ST}$ & $\mathrm{T}, \mathrm{ST}$ & $\mathrm{C}, \mathrm{ST}, \mathrm{T}$ & $\mathrm{C}, \mathrm{ST}, \mathrm{T}$ & $\mathrm{T}$ & ST \\
\hline Anaerobic growth & - & - & + & - & - & + & + & + & - & - & + & - \\
\hline Temperature range $\left({ }^{\circ} \mathrm{C}\right)$ & $10-50$ & $15-50$ & $10-45$ & $20-45$ & $10-40$ & $15-50$ & $15-50$ & $15-50$ & $10-40$ & $15-45$ & $10-45$ & $5-45$ \\
\hline \multicolumn{13}{|l|}{ Growth at/in: } \\
\hline $0 \%(\mathrm{w} / \mathrm{v}) \mathrm{NaCl}$ & + & - & - & + & - & ND & ND & + & W & - & - & + \\
\hline $20 \%(\mathrm{w} / \mathrm{v}) \mathrm{NaCl}$ & + & - & + & $\mathrm{v}(+)$ & - & - & - & + & - & + & - & - \\
\hline pH 10 & + & - & - & - & ND & - & - & ND & ND & + & - & + \\
\hline \multicolumn{13}{|l|}{ Hydrolysis of: $\ddagger$} \\
\hline Aesculin & - & + & $\mathrm{v}(-)$ & $\mathrm{v}(+)$ & $\mathrm{w}$ & + & + & + & - & + & + & ND \\
\hline Casein & - & + & $-\S$ & $\mathrm{v}(+)$ & + & + & + & + & + & + & ND & ND \\
\hline Gelatin & - & + & + & + & - & $\mathrm{V}$ & + & + & $\mathrm{W}$ & + & - & ND \\
\hline Starch & + & - & - & + & ND & ND & ND & + & $\mathrm{ND}$ & - & ND & ND \\
\hline $\mathrm{H}_{2} \mathrm{~S}$ production $\ddagger$ & - & + & - & ND & - & - & $\mathrm{v}$ & - & - & + & - & - \\
\hline Nitrate reduction $\ddagger$ & + & + & + & + & + & - & $\mathrm{v}$ & - & + & - & - & + \\
\hline \multicolumn{13}{|l|}{ Acid production from: } \\
\hline $\mathrm{N}$-Acetylglucosamine & - & + & + & ND & - & + & + & + & $\mathrm{w}$ & $\mathrm{w}$ & - & + \\
\hline D-Galactose & - & - & + & - & - & + & - & + & - & $\mathrm{W}$ & - & $\mathrm{W}$ \\
\hline D-Glucose & + & + & + & - & - & + & - & + & $\mathrm{w}$ & $\mathrm{w}$ & $\mathrm{W}$ & + \\
\hline D-Fructose & - & + & $\mathrm{v}(+)$ & + & - & + & - & + & $\mathrm{W}$ & $\mathrm{W}$ & + & + \\
\hline D-Mannitol & $\mathrm{W}$ & - & + & - & - & + & - & - & - & - & - & + \\
\hline D-Mannose & - & + & + & - & - & + & - & + & $\mathrm{w}$ & $\mathrm{w}$ & - & + \\
\hline Trehalose & $\mathrm{W}$ & - & + & ND & - & + & + & - & $\mathrm{W}$ & - & $\mathrm{W}$ & + \\
\hline \multicolumn{13}{|l|}{ Menaquinones (\%)\| } \\
\hline MK-6 & 6.1 & $1.8 \$$ & $2.0 \$$ & $\mathrm{ND}$ & 2 & 1 & 1 & Minor & 2 & 2 & ND & ND \\
\hline MK-7 & 93.2 & $97.6 \$$ & $97.7 \S$ & $\mathrm{ND}$ & 98 & 99 & 98 & $\mathrm{pr}$ & 97 & 98 & $\mathrm{pr}$ & $\mathrm{pr}$ \\
\hline MK-8 & 0.7 & $0.6 \$$ & $0.3 \S$ & $\mathrm{ND}$ & 1 & 1 & 1 & ND & $\operatorname{tr}$ & $\operatorname{tr}$ & $\mathrm{ND}$ & $\mathrm{ND}$ \\
\hline DNA G $+\mathrm{C}$ content $(\mathrm{mol} \%)$ & 41.8 & $39.0-42.8$ & $38-39$ & $30.7-33.4$ & 38.9 & $36.8-37.0$ & $36.9-38.3$ & 36.7 & 37.3 & $36.3-39.5$ & 41 & 42.6 \\
\hline
\end{tabular}

${ }^{\star}$ E, Ellipsoidal; S, spherical.

$\dagger$ C, Central; ST, subterminal; T, terminal.

¥Unless otherwise indicated, results of these tests for V. marismortui DSM $12325^{\mathrm{T}}$ and $V$. halodenitrificans DSM $10037^{\mathrm{T}}$ were confirmed in parallel tests with strain YIM kkny16 ${ }^{\mathrm{T}}$ under identical conditions.

$§$ Results for type strains from the present study.

IIData for type strains.

supplemented with $10 \%(\mathrm{w} / \mathrm{v}) \mathrm{NaCl}$ at $37{ }^{\circ} \mathrm{C}$, colonies are 2-3 $\mathrm{mm}$ in diameter, circular to slightly irregular, raised, translucent, creamy grey-coloured and slightly transparent at the edges. No soluble pigments are produced. Growth occurs in the presence of $0-25 \%(\mathrm{w} / \mathrm{v}) \mathrm{NaCl}$ [optimum, $10 \%(\mathrm{w} / \mathrm{v}) \mathrm{NaCl}]$ at $10-50{ }^{\circ} \mathrm{C}$ (optimum, $37{ }^{\circ} \mathrm{C}$ ) and at pH 6.0-10.0 (optimum, pH 7.0). Starch is hydrolysed, but casein, cellulose, chitin, aesculin, gelatin, and Tweens 20 and 80 are not. Nitrate is reduced to nitrite. $\mathrm{H}_{2} \mathrm{~S}$ production, indole, methyl red and Voges-Proskauer tests are negative. Cells are resistant to gentamicin $(10 \mu \mathrm{g})$, kanamycin $(30 \mu \mathrm{g})$, nalidixic acid $(20 \mu \mathrm{g})$ and streptomycin $(10 \mu \mathrm{g})$, but susceptible to ampicillin $(30 \mu \mathrm{g})$, chloramphenicol $(30 \mu \mathrm{g})$, lincomycin $(2 \mu \mathrm{g})$, novobiocin $(30 \mu \mathrm{g})$, polymyxin $\mathrm{B}(30 \mu \mathrm{g})$, rifampicin $(5 \mu \mathrm{g})$ and tetracycline $(30 \mu \mathrm{g})$. Acid is produced from D-glucose, glycogen, D-mannose, D-mannitol, salicin, starch and maltose, but not from amygdalin, inositol, potassium 5-ketogluconate, sucrose, D-sorbitol, Darabinose, L-arabinose, glycerol, erythritol, D-ribose, Dxylose, L-xylose, D-adonitol, methyl $\beta$-D-xylopyranoside, D-galactose, D-fructose, L-sorbose, L-rhamnose, dulcitol, methyl $\alpha$-D-mannopyranoside, methyl $\alpha$-D-glucopyranoside, $\mathrm{N}$-acetylglucosamine, arbutin, aesculin, D-cellobiose, Dlactose, melibiose, trehalose, inulin, melezitose, raffinose, 
Table 2. Whole-cell fatty acid profiles of strain YIM kkny $16^{\top}$ and related Virgibacillus species

Strains: 1, YIM kkny16 ${ }^{\mathrm{T}}$ (data from the present study); 2, V. marismortui KCTC $3845^{\mathrm{T}}$; 3, V. halodenitrificans $\mathrm{KCTC} 3790^{\mathrm{T}} ; 4$, V. olivae DSM $18098^{\mathrm{T}}$ (Quesada et al., 2007) 5, V. carmonensis KCTC $3819^{\mathrm{T}}$; 6, V. proomii KCTC $3822^{\mathrm{T}}$; 7, V. pantothenticus KCTC $3539^{\mathrm{T}}$; 8, V. dokdonensis KCTC $3933^{\mathrm{T}}$ (An et al., 2007); 9, V. necropolis KCTC $3820^{\mathrm{T}}$; 10. V. salexigens KCTC $3844^{\mathrm{T}}$; 11, V. koreensis KCTC $3823^{\mathrm{T}}$; 12, V. halophilus KCTC $13935^{\mathrm{T}}$ (An et al., 2007). All other data are from Lee et al. (2006). Data are percentages of the total fatty acids; components representing $<1.0 \%$ of the total are not shown.

\begin{tabular}{|c|c|c|c|c|c|c|c|c|c|c|c|c|}
\hline Fatty acid & 1 & 2 & 3 & 4 & 5 & 6 & 7 & 8 & 9 & 10 & 11 & 12 \\
\hline $\mathrm{C}_{15: 0}$ & & & & 1.1 & & & & & & & 5.1 & 1.4 \\
\hline $\mathrm{C}_{18: 0}$ & 2.1 & & & 1.2 & & & & & & & & \\
\hline $\mathrm{C}_{16: 1} \omega 7 c$ alcohol & 8.1 & 1.1 & 3.1 & 1.3 & 6.5 & & & & 2.4 & & 3.4 & \\
\hline $\mathrm{C}_{16: 1} \omega 11 c$ & & & & 1.7 & & & & & 1.0 & & 2.2 & \\
\hline Iso- $\mathrm{C}_{13: 0}$ & & & & & & & & 1.0 & & & & \\
\hline Anteiso- $\mathrm{C}_{13: 0}$ & & & & & & & & 1.8 & & & & \\
\hline Iso- $\mathrm{C}_{14: 0}$ & 13.3 & 2.9 & 7.4 & 2.1 & 3.3 & 2.4 & 2.3 & 2.1 & 2.2 & 4.2 & 8.3 & 5.6 \\
\hline Iso- $\mathrm{C}_{15: 0}$ & 2.6 & 39.0 & 2.4 & 33.7 & 5.7 & 15.1 & 7.1 & 15.5 & 3.8 & 34.0 & 6.1 & 21.2 \\
\hline Anteiso- $\mathrm{C}_{15: 0}$ & 50.4 & 33.9 & 51.8 & 28.4 & 58.29 & 38.5 & 55.3 & 47.0 & 67.9 & 30.5 & 43.4 & 35.8 \\
\hline Iso- $\mathrm{C}_{16: 0}$ & 6.1 & 4.3 & 11.8 & 3.9 & 6.4 & 7.3 & 7.2 & 3.7 & 4.2 & 8.4 & 14.4 & 10.3 \\
\hline
\end{tabular}

${ }^{*}$ Summed features: $3, \mathrm{C}_{16: 1} \omega 7 c$ and/or iso- $\mathrm{C}_{15: 0} 2-\mathrm{OH} ; 4$, iso- $\mathrm{C}_{15: 0} 2-\mathrm{OH}$ and/or $\mathrm{C}_{16: 1} \omega 7 t$.

xylitol, gentiobiose, turanose, D-lyxose, D-tagatose, D-fucose, L-fucose, D-arabitol, L-arabitol, potassium gluconate or potassium 2-ketogluconate. The following compounds are utilized as sole carbon and energy sources: $\beta$-cyclodextrin, dextrin, D-glucose, D-mannitol, D-mannose, D-ribose, salicin, trehalose, D-xylose, acetic acid, $\beta$-hydroxybutyric acid, $\alpha$ ketoglutaric acid, $\alpha$-ketovaleric acid, L-malic acid, monomethylsuccinate, pyruvic acid, succinic acid, D-alanine, L-alanine, L-glutamic acid, L-serine, 2 '-deoxyadenosine and inosine. Constitutive enzymes expressed are catalase,

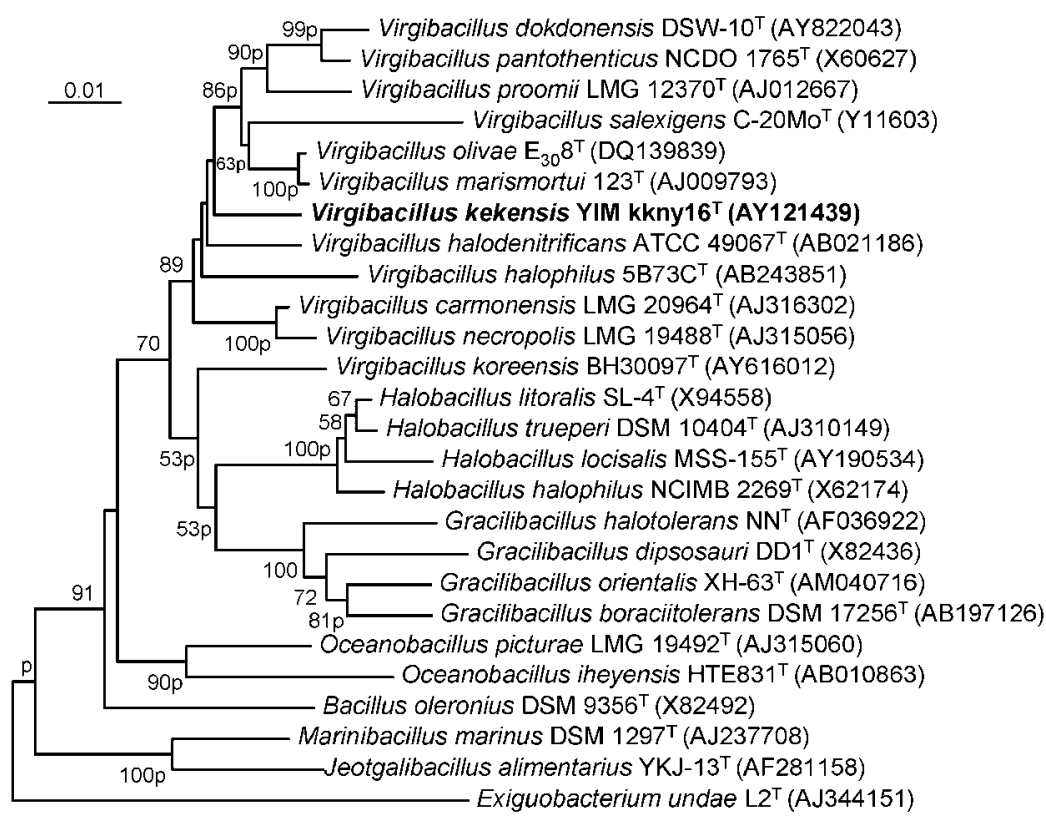

http://ijs.sgmjournals.org
Fig. 2. Neighbour-joining tree based on almost-complete 16S rRNA gene sequences, showing the phylogenetic position of strain YIM kkny $16^{\top}$ among recognized members of the genus Virgibacillus (Heyndrickx et al., 1998; Heyrman et al., 2003) and other related taxa. The label ' $p$ ' indicates branches that were also found with the maximum-parsimony algorithm (Kluge \& Farris, 1969). Numbers at nodes indicate bootstrap values ( $>50 \%$ ) based on neighbour-joining analysis of 1000 resampled datasets. Bar, 1 substitution per $100 \mathrm{nt}$. 
cytochrome oxidase, alkaline phosphatase, esterase (C4), esterase lipase (C8), leucine arylamidase, valine arylamidase, trypsin, $\alpha$-chymotrypsin, acid phosphatase, naphthol-AS-BIphosphohydrolase, $\beta$-glucuronidase, $\alpha$-glucosidase and $\beta$ glucosidase; lipase (C14), cystine arylamidase, $\alpha$-galactosidase, $\beta$-galactosidase, $N$-acetyl- $\beta$-glucosaminidase, $\alpha$-mannosidase, $\alpha$-fucosidase and urease are not produced. The predominant menaquinone is MK-7 (93\%), with significant amounts of MK-6 (6\%) and minor amounts of MK-8 (1\%) also present. Polar lipids are diphosphatidylglycerol, phosphatidylglycerol and two unknown phospholipids. Major cellular fatty acids (making up $84.9 \%$ of the total) are anteiso- $\mathrm{C}_{15: 0}$, iso- $\mathrm{C}_{14: 0}, \mathrm{C}_{16: 1} \omega 7 \mathrm{c}$ alcohol, anteiso$\mathrm{C}_{17: 0}$ and iso- $\mathrm{C}_{16: 0}$. The DNA G $+\mathrm{C}$ content is $41.8 \mathrm{~mol} \%$.

The type strain is YIM kkny16 ${ }^{\mathrm{T}}\left(=\mathrm{DSM} 17056^{\mathrm{T}}=\right.$ CGMCC $1.6298^{\mathrm{T}}$ ), which is the isolate on which the species description is based. It was isolated from a saline mud sample collected from the Keke salt lake in the Qaidam basin in Qinghai Province, north-west China.

\section{Acknowledgements}

This study was supported by grants from the National Natural Science Foundation of China (NSFC) (30460004, 30660004, 30760006 and 30560001), SRF for ROCS (SEM), the Yunnan Provincial Sciences and Technology Department (2005PY01-1, 2004C0002Z and $2006 \mathrm{C} 0006 \mathrm{M})$ and the Ministry of Science and Technology of China (973 Program, no. 2004CB719601; 863 Program, no. 2007AA021306). We are grateful to Dr Jean Euzéby for recommending the proper etymology and to Ms Li-Xia Duan for her excellent technical assistance.

\section{References}

An, S.-Y., Asahara, M., Goto, K., Kasai, H. \& Yokota, A. (2007). Virgibacillus halophilus sp. nov., spore-forming bacteria isolated from soil in Japan. Int J Syst Evol Microbiol 57, 1607-1611.

Arahal, D. R., Marquez, M. C., Volcani, B. E., Schleifer, K. H. \& Ventosa, A. (1999). Bacillus marismortui sp. nov., a new moderately halophilic species from the Dead Sea. Int J Syst Bacteriol 49, 521-530.

Arahal, D. R., Marquez, M. C., Volcani, B. E., Schleifer, K. H. \& Ventosa, A. (2000). Reclassification of Bacillus marismortui as Salibacillus marismortui comb. nov. Int J Syst Evol Microbiol 50, 1501-1503.

Atlas, R. M. (1993). Handbook of Microbiological Media. Edited by L. C. Parks. Boca Raton, FL: CRC Press.

Chen, H.-H., Li, W.-J., Tang, S.-K., Kroppenstedt, R.-M., Stackbrandt, E., Xu, L.-H. \& Jiang, C.-L. (2004). Corynebacterium halotolerans sp. nov., isolated from saline soil in the west of China. Int J Syst Evol Microbiol 54, 779-782.

Collins, M. D. \& Jones, D. (1980). Lipids in the classification and identification of coryneform bacteria containing peptidoglycans based on 2,4-diaminobutyric acid. J Appl Bacteriol 48, 459-470.

Cui, X.-L., Mao, P.-H., Zeng, M., Li, W.-J., Zhang, L.-P., Xu, L.-H. \& Jiang, C.-L. (2001). Streptomonospora salina gen. nov., sp. nov., a new member of the family Nocardiopsaceae. Int J Syst Evol Microbiol 51, 357-363.

Doetsch, R. N. (1981). Determinative methods of light microscopy. In Manual of Methods for General Bacteriology, pp. 21-33. Edited by
P. Gerhardt, R. G. E. Murray, R. N. Costilow, E. W. Nester, W. A. Wood, N. R. Krieg \& G. H. Phillips. Washington, DC: American Society for Microbiology.

Ezaki, T., Hashimoto, Y. \& Yabuuchi, E. (1989). Fluorometric deoxyribonucleic acid-deoxyribonucleic acid hybridization in microdilution wells as an alternative to membrane filter hybridization in which radioisotopes are used to determine genetic relatedness among bacterial strains. Int J Syst Bacteriol 39, 224-229.

Felsenstein, J. (1985). Confidence limits on phylogenies: an approach using the bootstrap. Evolution 39, 783-791.

Felsenstein, J. (1993). PHYLIP (phylogeny inference package), version 3.5c. Distributed by the author. Department of Genome Sciences, University of Washington, Seattle, USA.

Garabito, M. J., Arahal, D. R., Mellado, E., Marquez, M. C. \& Ventosa, A. (1997). Bacillus salexigens sp. nov., a new moderately halophilic Bacillus species. Int J Syst Bacteriol 47, 735-741.

Gerhardt, P., Murray, R. G. E., Costilow, R. N., Nester, E. W., Wood, W. A., Krieg, N. R. \& Phillips, G. B. (editors) (1981). Manual of Methods for General Bacteriology. Washington, DC: American Society for Microbiology.

Gregersen, T. (1978). Rapid method for distinction of Gram-negative from Gram-positive bacteria. Eur J Appl Microbiol Biotechnol 5, 123-127.

Groth, I., Schumann, P., Weiss, N., Martin, K. \& Rainey, F. A. (1996). Agrococcus jenensis gen. nov., sp. nov., a new genus of actinomycetes with diaminobutyric acid in the cell wall. Int J Syst Bacteriol 46, 234-239.

Hasegawa, T., Takizawa, M. \& Tanida, S. (1983). A rapid analysis for chemical grouping of aerobic actinomycetes. J Gen Appl Microbiol 29, 319-322.

Heyndrickx, M., Lebbe, L., Kersters, K., De Vos, P., Forsyth, G. \& Logan, N. A. (1998). Virgibacillus: a new genus to accommodate Bacillus pantothenticus (Proom and Knight 1950). Emended description of Virgibacillus pantothenticus. Int J Syst Bacteriol 48, 99-106.

Heyndrickx, M., Lebbe, L., Kersters, K., Hoste, B., De Wachter, R., De Vos, P., Forsyth, G. \& Logan, N. A. (1999). Proposal of Virgibacillus proomii sp. nov. and emended description of Virgibacillus pantothenticus (Proom and Knight 1950) Heyndrickx et al. 1998. Int J Syst Bacteriol 49, 1083-1090.

Heyrman, J., Logan, N. A., Busse, H.-J., Balcaen, A., Lebbe, L., Rodriguez-Diaz, M., Swings, J. \& De Vos, P. (2003). Virgibacillus carmonensis sp. nov., Virgibacillus necropolis sp. nov. and Virgibacillus picturae sp. nov., three novel species isolated from deteriorated mural paintings, transfer of the species of the genus Salibacillus to Virgibacillus, as Virgibacillus marismortui comb. nov. and Virgibacillus salexigens comb. nov., and emended description of the genus Virgibacillus. Int J Syst Evol Microbiol 53, 501-511.

Hopwood, D. A., Bibb, M. J., Chater, K. F., Kieser, T., Bruton, C. J., Kieser, H. M., Lydiate, D. J., Smith, C. P. \& Ward, J. M. (1985). Preparation of chromosomal, plasmid and phage DNA. In Genetic Manipulation of Streptomyces - a Laboratory Manual, pp. 79-80. Edited by D. A. Hopwood, M. J. Bibb, K. F. Chater, T. Kieser, C. J. Bruton, H. M. Kieser, D. J. Lydiate, C. P. Smith, J. M. Ward \& H Schrempf. Norwich, UK: F. Crowe \& Sons.

Kimura, M. (1980). A simple method for estimating evolutionary rates of base substitutions through comparative studies of nucleotide sequences. J Mol Evol 16, 111-120.

Kluge, A. G. \& Farris, F. S. (1969). Quantitative phyletics and the evolution of anurans. Syst Zool 18, 1-32.

Kumar, S., Tamura, K. \& Nei, M. (2004). MEGA3: integrated software for molecular evolutionary genetics analysis and sequence alignment. Brief Bioinform 5, 150-163. 
Lee, J.-S., Lim, J.-M., Lee, K. C., Lee, J.-C., Park, Y.-H. \& Kim, C.-J. (2006). Virgibacillus koreensis sp. nov., a novel bacterium from a salt field, and transfer of Virgibacillus picturae to the genus Oceanobacillus as Oceanobacillus picturae comb. nov. with emended descriptions. Int J Syst Evol Microbiol 56, 251-257.

Mandel, M. \& Marmur, J. (1968). Use of ultraviolet absorbancetemperature profile for determining the guanine plus cytosine content of DNA. Methods Enzymol 12B, 195-206.

Minnikin, D. E., Collins, M. D. \& Goodfellow, M. (1979). Fatty acid and polar lipid composition in the classification of Cellulomonas, Oerskovia and related taxa. J Appl Bacteriol 47, 87-95.

Proom, H. \& Knight, B. C. (1950). Bacillus pantothenticus (n.sp.). J Gen Microbiol 4, 539-541.

Quesada, T., Aguilera, M., Morillo, J. A., Ramos-Cormenzana, A. \& Monteoliva-Sánchez, M. (2007). Virgibacillus olivae sp. nov., isolated from waste wash-water from processing of Spanish-style green olives. Int J Syst Evol Microbiol 57, 906-910.

Saitou, N. \& Nei, M. (1987). The neighbor-joining method: a new method for reconstructing phylogenetic trees. Mol Biol Evol 4, 406-425.

Shirling, E. B. \& Gottlieb, D. (1966). Methods for characterization of Streptomyces species. Int J Syst Bacteriol 16, 313-340.

Smibert, R. M. \& Krieg, N. R. (1981). General characterization. In Manual of Methods for General Microbiology, pp. 409-443. Edited by P. Gerhardt, R. G. E. Murray, R. N. Costilow, E. W. Nester, W. A. Wood, N. R. Krieg \& G. B. Phillips. Washington, DC: American Society for Microbiology.

Stackebrandt, E. \& Ebers, J. (2006). Taxonomic parameters revisited: tarnished gold standards. Microbiol Today 33, 152-155.

Stackebrandt, E. \& Goebel, B. M. (1994). Taxonomic note: a place for DNA-DNA reassociation and $16 \mathrm{~S}$ rRNA sequence analysis in the present species definition in bacteriology. Int J Syst Bacteriol 44, 846-849.

Stackebrandt, E. \& Liesack, W. (1993). Nucleic acids and classification. In Handbook of New Bacterial Systematics, pp. 152-189. Edited by M. Goodfellow \& A. G. O’Donnell. London: Academic Press.

Staneck, J. L. \& Roberts, G. D. (1974). Simplified approach to identification of aerobic actinomycetes by thin-layer chromatography. Appl Microbiol 28, 226-231.

Thompson, J. D., Gibson, T. J., Plewniak, F., Jeanmougin, F. \& Higgins, D. G. (1997). The CLUSTAL_X windows interface: flexible strategies for multiple sequence alignment aided by quality analysis tools. Nucleic Acids Res 25, 4876-4882.

Wainø, M., Tindall, B. J., Schumann, P. \& Ingvorsen, K. (1999). Gracilibacillus gen. nov., with description of Gracilibacillus halotolerans gen. nov., sp. nov.; transfer of Bacillus dipsosauri to Gracilibacillus dipsosauri comb. nov., and Bacillus salexigens to the genus Salibacillus gen. nov., as Salibacillus salexigens comb. nov. Int J Syst Bacteriol 49, 821-831.

Wayne, L. G., Brenner, D. J., Colwell, R. R., Grimont, P. A. D., Kandler, O., Krichevsky, M. I., Moore, L. H., Moore, W. E. C., Murray, R. G. E. \& other authors (1987). International Committee on Systematic Bacteriology. Report of the ad hoc committee on reconciliation of approaches to bacterial systematics. Int J Syst Bacteriol 37, 463-464.

Yoon, J.-H., Oh, T.-K. \& Park, Y.-H. (2004). Transfer of Bacillus halodentitrificans Denariaz et al. 1989 to the genus Virgibacillus as Virgibacillus halodenitrificans comb. nov. Int J Syst Evol Microbiol 54, 2163-2167.

Yoon, J.-H., Kang, S.-J., Lee, S.-Y., Lee, M.-H. \& Oh, T.-K. (2005). Virgibacillus dokdonensis sp. nov., isolated from a Korean island, Dokdo, located at the edge of the East Sea in Korea. Int J Syst Evol Microbiol 55, 1833-1837. 